\title{
Primary aldosteronism - recent progress and current concepts
}

\author{
Pierwotny hiperaldosteronizm — współczesne oblicze problemu, \\ postępy w diagnostyce i leczeniu
}

\section{Sylwia Kołodziejczyk-Kruk', Włodzimierz Januszewicz, Mariola Pęczkowska' , Aleksander Prejbisz', Wojciech Zgliczyński ${ }^{2}$, Andrzej Januszewicz'}

${ }^{1}$ Department of Hypertension, Institute of Cardiology, Warsaw, Poland

${ }^{2}$ Department of Endocrinology, Centre for Postgraduate Medical Education, Warsaw, Poland

\begin{abstract}
Primary aldosteronism is the commonest form of hormone-related hypertension, with an estimated prevalence of 6-13\% in the general population of hypertensive patients. Among patients with resistant hypertension, the proportion of PA is even higher. Through intensive research in the field of basic science and the creation of large registries of patients with PA, it is possible to understand the effect of excess aldosterone not only on the cardiovascular system but also on the morphology and function of the other organs. Recent research has highlighted the differences in the regulation of calcium metabolism in patients with adrenal adenomas and PA. A lot of attention has been paid to the improvement of diagnostic methods, with particular emphasis on adrenal vein sampling, which is becoming increasingly important. In recent years there have been many publications on the prevalence of mutations in the potassium channel in patients with adrenal tumours and PA. A new form of familial hyperaldosteronism - FIII, has also been distinguished. Treatment of patients with PA still relies on the use of mineralocorticoid receptor antagonists or adrenalectomy, preferably preceded by a confirmation of aldosterone secretion lateralisation by adrenal vein sampling. (Endokrynol Pol 2013; 64 (4): 312-318)
\end{abstract}

Key words: adrenalectomy, adrenal vein sampling (AVS), aldosterone-to-renin ratio (ARR), KCNJ5 mutation, mineralocorticoid receptor antagonist, primary aldosteronism (PA), KCNJ5 mutation

\section{Streszczenie}

Pierwotny hiperaldosteronizm (PA) to najczęstsza postać nadciśnienia tętniczego uwarunkowanego hormonalnie, którego częstość w ogólnej populacji chorych na nadciśnienie tętnicze szacuje się na 6-13\%. Wśród pacjentów z nadciśnieniem tętniczym opornym na leczenie odsetek chorych z PA jest jeszcze większy. Dzięki intensywnym badaniom z dziedziny nauk podstawowych i tworzeniu dużych rejestrów chorych z PA poznawany jest wpływ nadmiaru aldosteronu nie tylko na układ sercowo-naczyniowy, ale również na morfologię i funkcję pozostałych organów . W najnowszych badaniach podkreśla się odmienności w regulacji gospodarki wapniowej u chorych z gruczolakiem nadnercza i PA. Wiele miejsca poświęca się doskonaleniu metod diagnostyki, ze szczególnym uwzględnieniem cewnikowania żył nadnerczowych, które zyskuje coraz większe znaczenie. W ciągu ostatniego roku pojawiło się wiele publikacji dotyczących występowania mutacji w kanale potasowym u chorych z guzem nadnercza i PA. Wyodrębniono również nową postać rodzinnie występującego hiperaldosteronizmu - FIII.

Leczenie pacjentów z PA w dalszym ciągu opiera się na stosowaniu antagonistów receptora dla mineralokortykoidów lub adrenalektomii, optymalnie poprzedzonej potwierdzeniem lateralizacji w wydzielaniu aldosteronu za pomocą cewnikowania żył nadnerczowych. (Endokrynol Pol 2013; 64 (4): 312-318)

Słowa kluczowe: adrenalektomia, antagoniści receptora dla mineralokortykoidów, cewnikowanie żył nadnerczowych, mutacja genu KCNJ5, pierwotny hiperaldosteronizm, wskaźnik aldsteronowo-reninowy

\section{Introduction}

Primary aldosteronism as a form of secondary hypertension was distinguished in 1954 by the American clinician Jerome Conn, who demonstrated a causal relationship between the development of hypertension and adrenocortical adenoma producing aldosterone. The first report on two patients in whom hypertension development was associated with adenomas of adrenal glomerulosa was presented in 1953 in the Polish Medical Weekly (Polski Tygodnik Lekarski) by the Polish physician Michał Lityński [1,2].

Since then, especially over the past few years, there has been significant progress in understanding the pathogenesis and improving diagnosis and treatment of primary aldosteronism.

Many clinical centres dealing with primary aldosteronism create large international registries of patients, 
which allow us to learn about the clinical profile and genetic background of this disease as well as to improve diagnosis and treatment, and ensure a long-term follow-up. Great hopes are associated with studies on the genetic background of primary aldosteronism. In recent years there have been many publications evaluating the presence of mutations in the potassium channel in different groups of patients with primary aldosteronism.

In this paper we present current views on the occurrence, pathogenesis, diagnosis and treatment of the commonest form of hormone-related arterial hypertension.

\section{Incidence}

Primary aldosteronism (PA) is the commonest form of hormone-related arterial hypertension [1,2]. Therefore, it is not surprising that in the world literature much attention has been paid to the pathogenetic and clinical aspects of this form of secondary hypertension. It is worth mentioning that expert recommendations concerning diagnosis and treatment of PA [3-6] have recently been published.

In the present study we focus on the recent studies that have brought new elements to our knowledge of primary aldosteronism. There is an ongoing discussion concerning evaluation of the real prevalence of PA [7, 8]. In recent studies the incidence of PA in the general population of hypertensive patients has been found to be $6-13 \%$ [7-9].

In a large prospective study of 1,180 Italian patients with newly diagnosed arterial hypertension (known by the acronym PAPY), primary aldosteronism was diagnosed in $11 \%$ of patients [9].

The literature emphasises that PA often affects patients with refractory arterial hypertension. The following studies, evaluating a relationship between refractory hypertension and primary aldosteronism, deserve particular attention:

Douma et al. evaluated the incidence of primary aldosteronism in 1,616 patients with refractory hypertension. This study demonstrated that one in ten patients with refractory hypertension suffered from primary aldosteronism [10].

Calhoun et al. evaluated 88 patients with refractory hypertension; primary aldosteronism was diagnosed in every fifth patient (20\%) [11].

Gallay et al. studied 90 patients with poorly controlled arterial hypertension; secondary hypertension was diagnosed in $17 \%$ of patients [12].

Eide et al. evaluated 90 patients with refractory hypertension; primary aldosteronism was diagnosed in $23 \%$ of patients [13].
The results of the above studies indicate that the incidence of primary aldosteronism in patients with refractory hypertension is in the range of 11-23\% [10-13].

The results of studies carried out between 2009 and 2012 in the Department of Hypertension at the Institute of Cardiology in Warsaw within the RESISTPOL registry, which enrolled 204 patients with true refractory hypertension, should also be mentioned. Among the secondary causes of arterial hypertension, primary aldosteronism was commonest in this group of patients (in 16\% of patients). A relationship between primary aldosteronism and obstructive sleep apnoea (OSA)/metabolic syndrome was also demonstrated [14].

"Endocrine Society Clinical Practice Guideline" presented the opinion, based on cross-sectional and prospective studies, that the incidence of PA in the general population of hypertensive patients and in those treated in specialist centres was more than $10 \%$ [4]. The Journal of Hypertension has presented an interesting debate on primary aldosteronism led by two prominent experts in arterial hypertension: Kaplan and Funder [15, 16]. Kaplan is of the opinion that PA does not occur as often as observed in studies published in recent years, and the diagnosis of this disease is too complex and expensive to be applied in all patients with arterial hypertension. However, he recommends a wider use of mineralocorticoid receptor antagonists in the treatment of arterial hypertension [15]. Funder partially agrees with Kaplan, in particular with regard to the possibility of more frequent use of mineralocorticoid receptor antagonists, but he draws attention to progress in the diagnosis and treatment of PA, and the fact that patients with PA have a very high cardiovascular risk [16]. However, it should be remembered that eplerenone, the use of which is associated with a much better tolerance than the use of spironolactone, has been registered in the United States (but not in Europe) for the treatment of arterial hypertension, and soon generic formulations of this drug will also be available in this country $[15,16]$.

\section{Pathogenesis and impact of aldosterone on cardiovascular complications}

Primary aldosteronism is a form of arterial hypertension characterised by heterogeneous pathogenesis. The differences regard the nature of adrenal abnormalities, clinical manifestation and genetic predisposition.

In recent decades, dynamic studies have demonstrated multiple biological properties of aldosterone, exceeding its classic effect on the water and electrolyte balance. It has been shown that aldosterone exerts proinflammatory effects, enhances formation of free oxygen radicals, promotes cardiac, vascular and renal fibrosis, activates $\mathrm{TGF}_{1}$ and $\mathrm{PAI}_{1}$, and influences the im- 
mune system [17-19]. Primary aldosteronism makes it possible to observe the clinical effects of excess production of aldosterone on the system.

Noteworthy are the studies carried out by $\mathrm{O}$. Steichen et al., involving 460 patients with PA. A higher incidence of heart failure $(7.4 \%$ v. 3.6\%), coronary heart disease $(5.6 \%$ v. $1 \%)$, and atrial fibrillation was observed in these patients, compared to a group of 1,291 patients with essential hypertension [20].

Other studies have demonstrated a thicker intimamedia complex in the carotid arteries of PA patients, compared to patients suffering from essential hypertension [21]. Attention should also be paid to studies that have shown a reduced arterial compliance, assessed using carotid-femoral pulse wave velocity and increased aortic augmentation index, compared to patients suffering from essential hypertension. Surgical removal of the adrenal adenoma resulted in a reduction of arterial stiffness [22]. Studies carried out by Italian authors have demonstrated changes in the structure of small resistance arteries in PA patients [23, 24]. There are also observations indicating a higher incidence rate of microalbuminuria in patients with PA $[25,26]$. There are also reports on a higher prevalence of metabolic disorders. Studies that demonstrated a higher incidence of metabolic syndrome in PA patients are also worth mentioning [27, 28]. It is important to stress that the mechanisms underlying the observed correlation have not been elucidated. Studies that revealed increased levels of oxidative stress and myocardial fibrosis factors, compared to patients with essential hypertension [29, 30], should also be mentioned.

Primary aldosteronism is very rarely accompanied by malignant hypertension [31,32]. A case of a young PA male patient with malignant hypertension and prominent left ventricular hypertrophy has recently been described [33]. Surgical removal of the adrenal adenoma resulted in normalisation of blood pressure, regression of left ventricular hypertrophy and systolic function improvement. The authors believe that both severe hypertension and direct damaging effects of aldosterone, as two independently acting factors, have caused prominent left ventricular hypertrophy [33].

It has been suggested that mineralocorticoid receptors present in cardiomyocytes may contribute to myocardial remodelling. Fluid retention in cardiomyocytes influenced by aldosterone, and intracardiac volume increase, accompanied by increased intramural stress - in-wall-stress - should also be taken into consideration $[17,34]$.

Studies aimed to verify the hypothesis postulating the effect of aldosterone on the secretion of parathyroid hormone (PTH) are also worth mentioning. Pilz et al. observed higher levels of PTH and lower serum calcium levels in PA patients, compared to patients with essential hypertension; PTH levels were significantly reduced as a result of the PA treatment (surgery or administration of mineralocorticoid receptor antagonist) [35]. Another study which included 44 patients with PA in the course of adrenocortical adenoma, and 61 patients with essential hypertension, demonstrated that PA patients had also significantly elevated plasma PTH levels $(31 \%)$, compared to patients suffering from essential hypertension. Surgical removal of the adenoma resulted in normalisation of plasma PTH levels and increased concentration of ionised calcium in serum; the results of another study involving the same group also indicated that elevated serum PTH levels might be useful in the differentiation of a PA type [36, 37].

\section{Diagnostic methods}

\section{Aldosterone-to-renin ratio (ARR)}

According to 'An Endocrine Society Clinical Practice Guideline', determination of aldosterone-to-renin ratio is currently the most reliable screening test for PA. The ratio of aldosterone to plasma renin activity (PRA), expressed in $\mathrm{ng} / \mathrm{dL}$ and $\mathrm{ng} / \mathrm{mL} / \mathrm{h}$, respectively, which exceeds 30 , indicates the diagnosis of PA [4].

It is believed that aldosterone-to-renin ratio, like all biochemical screening tests, is charged with falsepositive and false-negative results [38]. Thus, much emphasis has been placed on the importance of factors that may affect the reliability of this test. According to Kaplan, the commonest cause of false-positive test results is a low PRA value, which occurs in approximately $30 \%$ of patients with arterial hypertension [15].

Antihypertensive drugs may have a great impact on the result of ARR measurement [39]. In patients with severe hypertension, withdrawal of these drugs is often not possible. It is connected with the risk of serious cardiovascular complications [5]. It has been recently reported that anti-depressants reduce the value of ARR [40], while oral contraceptives increase this value [41]. One should bear in mind that some antihypertensive drugs may only slightly affect the reliability of the test. These include hydralazine, verapamil or doxazosin [4].

The lower detection limit of plasma renin activity has a great impact on the value of ARR. It can vary for individual laboratory kits. The threshold value of PRA detection should not be less than $0.2 \mathrm{ng} / \mathrm{mL} / \mathrm{h}$. Progress in the methods for PRA measurement have allowed the determination of its values below $0.6 \mathrm{ng} /$ $\mathrm{mL} / \mathrm{h}$. The difference between 0.1 and $0.2 \mathrm{ng} / \mathrm{mL} / \mathrm{h}$ can be physiologically negligible, but it doubles the value of aldosterone-to-renin ratio $[1,2,3]$. 


\section{Adrenal Vein Sampling (AVS)}

Adrenal vein sampling is the method of choice in the differentiation of a PA. It enables identification of the source of increased secretion of aldosterone. This is important because the detection of adrenocortical adenoma secreting the excess of aldosterone is an indication for surgical treatment, whereas bilateral adrenal hyperplasia is an indication for conservative treatment [4].

"An Endocrine Society Clinical Practice Guideline" presents an opinion that AVS is the gold standard in the diagnosis of lateralisation of changes in the adrenal glands in patients with PA. It was emphasised that the test can be performed only in specialist centres by properly trained staff [4]. In recent years, there have been many publications devoted to assessing the diagnostic usefulness of this method [42-49].

It is worth mentioning that in a retrospective study evaluating surgical treatment in 168 patients, the diagnosis of adrenocortical adenomas was established by means of computed tomography or AVS. Normalised or improved blood pressure control was achieved in 77\% of patients with unilateral adenoma. The usefulness of AVS in patients with a typical clinical manifestation of PA, in whom visualisation revealed no changes in the adrenal glands, has been demonstrated [50].

We should also remember the studies carried out by Italian authors, which were devoted to the assessment of the diagnostic value of AVS. The study included 151 consecutive patients who underwent AVS; the limit value of laterality index for the differentiation between unilateral changes (adenoma) and bilateral adrenal hyperplasia was assessed. The study demonstrated the usefulness of this index in the differentiation of changes, highlighted the safety of the method and the importance of great experience of the staff performing the test [51].

While discussing the diagnostic utility of AVS, we cannot overlook the meta-analysis published in 2009 [52]. This demonstrated that a unilateral change in the adrenal glands observed during imaging examination was consistent with the result of AVS only in $67 \%$ of patients. The interpretation of the results was complicated by the fact that the results of surgical treatment were not given. Therefore, it is not possible to decide which of these methods was reliable in cases where the results of both examinations were not consistent [52].

Extensive studies carried out by Italian authors are also worth mentioning. They concerned patients with adrenocortical adenomas treated surgically. The authors demonstrated sensitivity and specificity of AVS of $80 \%$ and $75 \%$, respectively [53].

There are also observations indicating the disappearance of humoral changes in almost $100 \%$ of patients with adrenal adenoma treated surgically. Only $20 \%$ of patients underwent AVS before surgery; in the remaining patients, adrenal adenoma was diagnosed on the basis of imaging examinations [54].

Plouin et al. are of the opinion that the diagnostic usefulness of adrenal venous sampling can be assessed based on its ability to predict the effectiveness of surgical treatment. No differences were observed for the results of surgical treatment between patients in whom AVS was performed routinely and patients in whom this examination was performed selectively (39\% v.42\%). The authors have stated that the abovementioned data suggests a more critical assessment of the usefulness of AVS. Selective rather than routine AVS can reduce the nuisance value of the examination, without any serious damage to the patient [55].

According to American experts, who expressed their opinion in published guidelines, AVS should be performed more frequently. Regarding the fact that these guidelines are based on poorly documented (according to Evidence Based Medicine) studies, AVS may be skipped in selected cases with a typical image of adenoma during visualisation [6].

\section{Genetic tests}

In recent years, significant progress in understanding the genetic background of PA has been observed [56-58]. In 2011, Science published an innovative work by Choi et al. concerning genetic aspects of PA in relation to adrenocortical adenoma [59]. The authors demonstrated a mutation of KCNJ5 gene encoding the potassium channel Kir 3.4 in eight out of 22 adenomas obtained from patients with PA $(36 \%)$. The mutation was more common in younger patients and in women. Patients with a detected mutation were characterised by a higher aldosterone-to-renin rate compared to other patients [59].

In a large study based on material collected in nine clinical centres in France, Germany and Italy, somatic mutations of KCNJ5 gene were found in 34\% of adrenocortical tumours; a higher incidence of KCNJ5 mutations was observed in younger patients and in women. In patients with a somatic mutation of KCNJ5 gene within the adenoma, higher plasma aldosterone levels were observed than in patients without mutations. In all the patients with adenomas and bilateral hyperplasia in the course of PA, no germinal mutations of KCNJ5 were found [60]. However, in studies conducted in Australia and England, which included 73 patients with PA and adrenocortical adenomas, in $41 \%$ of tumours somatic mutations of KCNJ5 gene were found. Tumours with somatic mutations of KCNJ5 gene were significantly larger $(1.61 v .1 .04 \mathrm{~cm})$. The presence of somatic mutations of KCNJ5 gene was associated with the lack of aldosterone level response to verticalisation, which according to the authors might indicate a different 
phenotype of tumours with these mutations [61]. We should also take into account the opinion expressed by many authors that somatic mutations of the potassium channel gene KCNJ5 are just one of many stages of the complex pathogenesis of aldosterone-secreting adrenal adenomas [56, 57, 62, 63]

Germinal mutations of KCNJ5 gene were also found in the newly separated severe form of PA — familial type III PA [59]. In another work, mutations of KCNJ5 gene associated with the familial type III PA were described. The authors demonstrated that in contrast to previous descriptions, mutations of this gene may be associated not just with a very severe course of the disease [64]. In another paper describing families affected by the familial type III $\mathrm{PA}$, it has been shown that the site of KCNJ5 mutations has a direct impact on the functioning of the potassium channel and course of the disease, which can be very severe (requiring bilateral adrenalectomy) or mild (easily controlled arterial hypertension, no anatomical changes in the adrenal glands) [65].

\section{Treatment}

Treatment of primary aldosteronism should be initiated as early as possible, in order to prevent cardiovascular, renal and cerebral complications, caused by excess aldosterone.

Interesting results were obtained from investigations carried out under the TAIPAI Study. They were aimed to analyse the impact of surgical treatment of PA associated with adrenocortical adenoma on the regression of myocardial fibrosis. This prospective study included 20 patients with PA treated from 2006 to 2008. The control group consisted of 20 patients with essential hypertension. The authors measured the concentration of carboxy-terminal propetide of type 1 procollagen PICP, which is an indicator of the formation of type 1 collagen. In addition, echocardiography was performed using ultrasonic tissue characterisation by cyclic variations of integrated backscatter (CVIBS). Patients with PA had higher systolic and diastolic blood pressure, higher plasma aldosterone concentration, and higher aldosterone-to-renin ratio than patients with essential hypertension. In addition, they were characterised by a higher left ventricular mass index. In these patients, significantly lower CVIBS values and significantly higher PICP levels were observed compared to patients suffering from essential hypertension, which could indicate increased myocardial fibrosis. One year after the surgical removal of the adrenal adenoma, increased CVIBS values and decreased plasma PICP concentrations were observed [66].

In conclusion, the authors state that the obtained results demonstrated, for the first time in the literature, the regression of myocardial fibrosis in patients with PA after surgical removal of adrenal adenoma. An interesting observation indicated a correlation between CVIBS and plasma aldosterone levels/plasma renin activity rather than blood pressure. This may indicate that myocardial fibrosis is more dependent on hormonal changes than on high blood pressure [66].

French authors conducted studies assessing the impact of surgical removal of adrenal adenoma in PA patients on arterial blood pressure and antihypertensive treatment [67]. The study included 156 consecutive patients with adrenocortical adenoma, treated surgically at a single clinical centre from 2001 to 2009. Adrenalectomy resulted in normalisation of blood pressure in 68 patients $(44 \%)$. In the remaining patients, a decrease in blood pressure of $21-31 \%$ and a reduction in the number of used antihypertensive drugs by 1 (scale 1-3) was observed. The achieved hypotensive effect of surgical treatment was more pronounced in patients with higher blood pressure values in the preoperative period and a higher concentration of sodium in plasma. Achieving normalisation of blood pressure was less likely in patients with a longer duration of hypertension, higher blood pressure values, more antihypertensive drugs used, and reduced urinary aldosterone excretion. The authors are of the opinion that patients with PA and severe arterial hypertension receive substantial benefit from surgical treatment. However, normalisation of the blood pressure is less likely [67].

Studies based on the German register of primary aldosteronism are particularly noteworthy [68]. Mortality was assessed in 350 patients with PA treated at three clinical centres in Germany. The control group consisted of 600 individuals with normal blood pressure, and 600 hypertensive patients from population studies in Germany. After diagnosis and initiation of therapy, PA patients were followed from 1994. The analysis of the results was carried out in 2009 and 2010. The analysed parameters were evaluated in the 2:1 system. Analysis of the results showed that the overall mortality in PA patients did not differ from mortality in patients with essential hypertension. Cardiovascular events were the main cause of death in patients with PA $-50 \% v$. $34 \%$ in hypertensive patients in the control group [66].

The obtained results suggest that cardiovascular deaths are more common in treated PA patients during a long-term follow-up. In PA patients, age, coexisting diabetes and coronary artery disease were associated with a higher risk of death. The abovementioned studies assessed, for the first time in literature, mortality in treated PA patients during a long-term follow-up. It should be stressed that Kaplan-Meier survival curves were deviated in PA patients after six years. The authors emphasise the need for a long-term follow-up of 
treated PA patients and strict control of coexisting risk factors. This applies especially to patients whose high blood pressure persisted after adrenalectomy, or whose treatment with aldosterone antagonists was not entirely satisfactory [68].

As mentioned before, the method of choice in patients with idiopathic adrenal hyperplasia is pharmacological treatment with spironolactone or eplerenone [1-4].

A study aimed to compare the antihypertensive efficacy of both aldosterone antagonists in patients with PA should also be mentioned. This was a prospective, randomised and open study lasting for 24 weeks, which included 34 patients with bilateral adrenal hyperplasia. Eplerenone was used at a dose of 50-200 mg/day, and spironolactone at a dose of $50-400 \mathrm{mg} /$ day. The results demonstrated that both medicines had comparable antihypertensive effects [69].

Results of research carried out by Parthasarathy et al. should also be noted. This was a randomised, double-blind, multicentre trial involving two parallel and balanced groups of patients. The study included 141 patients with primary aldosteronism. For 16 weeks the subjects received eplerenone in increasing doses from 100 to $300 \mathrm{mg} /$ day and spironolactone in doses from 75 to $225 \mathrm{mg} /$ day. The hypotensive effect was more pronounced in patients treated with spironolactone than in those treated with eplerenone. Despite a more frequent occurrence of gynaecomastia, mastodynia and hyperkalaemia in patients receiving spironolactone, the overall incidence of undesirable effects was comparable in both treatment groups [70].

It is also worth mentioning that some observations have demonstrated a similar effectiveness of surgical treatment (adenoma) and pharmacotherapy with spironolactone. However, reports on the effectiveness of pharmacological treatment in PA patients in the course of adrenal adenomas are limited, and adrenalectomy remains the method of choice [71-73].

\section{Summary}

In conclusion, we must emphasise the constant progress in the improvement of diagnostic methods and treatment of primary aldosteronism. In particular, many achievements in this area can be expected from genetic studies.

\section{References}

1. Januszewicz A. Arterial hypertension An outline of the pathogenesis, diagnosis and treatment. Medycyna Praktyczna, Kraków 2009.

2. Więcek A, Januszewicz A, Szczepańska-Sadowska E, Prejbisz A. (ed.). Hypertensiology, pathogenesis, diagnosis and treatment of arterial hypertension. Medycyna Praktyczna, Kraków 2011.

3. Working Group of the Polish Society of Hypertension. Recommendations for the diagnosis and treatment of primary aldosteronism. Nadciśnienie Tetnicze 2008; 12: 155-168.
4. Funder JW, Carey RM, Fardella C et al. Case detection, diagnosis and treatment of patients with primary aldosteronism: An Endocrine Society Clinical Practice guideline. J Clin Endocrinol Metabo. 2008; 93: 3266-3281.

5. Fischer E, Beuschlein F, Bidlingmaier M and Reincke M. Commentary on the Endocrine Society Practice Guidelines: consequences of adjustment of antihypertensive medications in the screening of primary aldosteronism. Rev Endocr Metab Disord 2011; 12: 43-48.

6. Zeiger MA, Thompson GB, Duh QV et al. The American Association of Clinical Endocrinology and American Association of Endocrine Surgeons: Medical guidelines for the management of adrenal incidentalomas. Endocr Pract 2009; 15 (Suppl. 1): 1-20.

7. Hannemann A, Wallaschofski K. Prevalence of primary aldosteronism in patient cohort and in population-based studies: a review of the current literature. Horm Metab Res 2012; 44: 157-162.

8. Plouin PF, Amar L, Chatellier G. Trends in the prevalence of primary aldosteronism, aldosterone-producing adenomas and surgically correctable aldosterone - dependent hypertension. Nephrol Dial Transplant 2004; 19: 774-777.

9. Rossi GP, Bernini G, Caliumi C et al. A prospective study of the prevalence of primary aldosteronism in 1,125 hypertensive patients. Am Coll Cardiol 2005; 45: 1392-1396.

10. Douma S, Petidis K, Doumas M et al. Prevalence of primary aldosteronism in resistant hypertension: a retrospective observational study. Lancet 2008; 371: 1921-1926.

11. Calhoun DA, Nihizaka MK, Zaman MA et al. Hyperaldosteronism among black and white subjects with resistant hypertension. Hypertension 2002; 40: 892-896.

12. Gallay BJ, Ahmad S, Xu L et al. Screening for primary aldosteronism without discontinuing hypertensive medications: plasma aldosteronerenin ratio. Am J Kidney Dis. 2001; 37: 699-705.

13. Eide IK, Torjesen PA, Drolsum A et al. Low-renin status in therapyresistant hypertension: a clue to efficient treatment. J Hypertens 1996; 14: 1093-1097.

14. Florczak E, Prejbisz A, Szwench E et al. Clinical characteristics of patients with resistant hypertension: the RESIST-POL study. J Hum Hypertens 2013; Accepted

15. Kaplan NM. Primary aldosteronism: evidence against a second epidemic. J Hypertens 2012; 30: 1899-1902.

16. Funder JW. Ultimately we are in furious agreement. J Hypertens 2012; 30: 1903-1905.

17. Januszewicz W, Januszewicz A. Aldosterone - a hormone with multiple faces. Postępy Nauk Med 2009; 22: 750-755.

18. Brown NJ. Aldosterone and vascular inflammation. Hypertension 2008; 51: 161-167.

19. Herrada AA, Campino C, Amador CA et al. Aldosterone as a modulator of immunity: implications in the organ damage. Hypertens 2011; 29: 2684-2692.

20. Steichen O, Amar L, Plouin PF. Cardiovascular complications in patients with primary hyperaldosteronism: a controlled cross-sectional study. J Hypertens 2010; 28: e302-e303.

21. Bernini G, Galetta F, Franzoni E et al. Arterial stiffness, intima-media thickness and carotid artery fibrosis in patients with primary aldosteronism. Hypertens 2008; 26: 2399-2405.

22. Strauch B, Petrak O, Wichterle D et al. Increased arterial wall stiffness in primary aldosteronism in comparison with essential hypertension. Am J Hypertens. 2006; 19: 909-14.

23. Rizzoni D, Muiesan ML, Porteri E et al. Relationship between cardiac and vascular structure in patients with primary and secondary hypertension. J Am Coll Cardiol 1998; 32: 985-992.

24. Muiesan ML, Rizzoni D, Salvetti M et al. Structural changes in small resistance artieries and left ventricular structure geometry in patients with primary and secondary hypertension. Hypertens 2002; 20: 1439-1444.

25. Rossi GP, Bernini G, Desideri G et al. Renal damage in primary aldosteronism: results of PAPY study. Hypertension 2006; 48: 232-238.

26. Sechi LA, Novello $M$, Lapenna $R$ et al. Long-term renal outcomes in patients with primary aldosteronism. JAMA 2006; 295: 2638-2645.

27. Ronconi V, Turchi F, Rilli S et al. Metabolic syndrome in primary aldosteronism and essential hypertension: relationship to adiponectin gene variants. Natr Metab Cardiovasc Dis 2010; 20: 93-100.

28. Fallo F, Pilon C, Urbanet R. Primary aldosteronism and metabolic syndrome. Horm Metab Res. 2012; 44: 208-14.

29. Rossi GP, Di Bello V, Ganzaroli Ch et al. Excess aldosterone is associated with alterations of myocardial texture in primary aldosteronism. Hypertension 2002; 40: 23-27.

30. Stehr CB, Mellado R, Ocaranza MP et al. Increased levels of oxidative stress: subclinical inflammation and myocardial fibrosis markers in primary aldosteronism patients. J Hypertens 2010; 28: 2120-2126.

31. Zarifis J, Lip GY, Leatherdale B, Beevers G. Malignant hypertension in association with primary aldosteronism. Blood Press 1996; 5: 250-254.

32. Kaplan NM. Primary aldosteronism with malignant hypertension. N Engl J Med 1963; 269: 1282-1286. 
33. Prejbisz A, Klisiewicz A, Januszewicz A et al. A 22-year-old patient with malignant hypertension associated with primary aldosteronism. J Hum Hypertens 2013; 27: 138-140.

34. Gaddam K, Corros C, Pimenta E et al. Rapid reversal of left ventricular hypertrophy and intracardiac volume overload in patients with resistant hypertension and hyperaldosteronism: a prospective clinical study. Hypertension 2010; 55: 1137-1142.

35. Pilz S, Kienreich K, Drechsler C et al. Hyperparathyroidism in patients with primary aldosteronism: cross-sectional and interventional data from the GECOH study. J Clin Endocrinol Metab 2012; 97: E75-79.

36. Rossi GP, Ragazzo F, Seccia TM et al. Hyperparathyroidism can be useful in the identification of primary aldosteronism due to aldosteroneproducing adenoma. Hypertension 2012; 60: 431-436.

37. Maniero C, Fassina A, Seccia TM et al. Mild hyperparathyroidism: a novel surgically correctable feature of primary aldosteronism. Hypertens 2012; 30: 390-395.

38. Myśliwiec J, Zukowski L, Grodzka A et al. Problems in diagnostics of primary aldosteronism - analysis of the own data. Endokrynol Pol 2010; 61: 2-5.

39. Myśliwiec J, Górska M. Primary aldosteronism: a common and important problem. A practical guide to the diagnosis and treatment. Endokrynol Pol 2012; 63: 324-36.

40. Ahmed AH, Calvirol M, Gordon RD et al. Effects of two selective serotonin reuptake inhibitor antidepressants, sertraline and escitalopram on aldosterone/renin ratio in normotensive depressed male patients. J Clin Endocrinol Metab 2011; 96: 039-1045.

41. Ahmed AH, Gordon RD, Taylor PJ et al. Effect of contraceptives on aldosterone/renin assay ratio may vary according to the components of contraceptive, renin assay method and possibly route of administration. J Clin Endocrinol Metab 2011; 96: 1797-1804.

42. Stowasser H, Gordon RD, Gunasekera TG et al. High rate of detection of primary aldosteronism, including surgically treatable forms, after "non-selective" screening of hypertensive patients. Hypertens 2003; 21: 2149-2157.

43. Young WF, Stanson AW, Thompson GB et al. Role of adrenal vein sampling in primary aldosteronism. Surgery 2004; 136: 1227-1235.

44. Prejbisz A, Peczkowska M, Januszewicz A et al. Diagnosis of primary hyperaldosteronism - an ongoing discussion. Nadciśnienie Tętnicze 2004; 8: 205-217.

45. Giacchetti G, Ronconi V, Lucarelli G Boscaro M et al. Analysis of screening and confirmatory tests in the diagnosis of primary aldosteronism: need for a standardized protocol. Hypertens 2006; 24: 737-745.

46. Kline GA, Harvey A, Jones $C$ et al. Adrenal vein sampling may be not a gold-standard diagnostic test in primary aldosteronism: final diagnosis depends upon which interpretation rule is used. Variable interpretation of adrenal vein sampling. Int Urol Nephrol 2008; 40: 1035-1043.

47. Stewart PM, Allolio B. Adrenal vein sampling for primary aldosteronism: time for a reality check. Clin Endocrinol (Oxf) 2010; 72: 146-148.

48. Auchus RJ, Wians FHJr, Anderson ME et al. Role of adrenal vein sampling in primary aldosteronism. Horm Metab Res 2010; 42: 411-415.

49. Monticone S, Satoh F, Giacchetti G et al. Effect of adrenocorticotropic hormone stimulation during adrenal vein sampling in primary aldosteronism. Hypertension 2012; 59: 840-846.

50. Letavernier E, Peyrard S, Amar L et al. Blood pressure outcome of adrenalectomy in patients with primary hiperaldosteronism with or without unilateral adenoma. Hypertens 2008; 26: 1816-1823.

51. Rossi GP, Pitter G, Bernante P et al. Adrenal vein sampling for primary aldosteronism: the assessment of selectivity and lateralization of aldosterone excess baseline and after adrenocorticotropin hormone (ACTH) stimulation. Hypertens 2008; 26: 989-997.
52. Kempers MJ, Lenders JW, van Outheusden L et al. Systematic review: diagnostic procedures to differentiate unilateral from bilateral adrenal abnormality in primary aldosteronism. Ann Intern Med 2009; 151: 329-337.

53. Toniato A, Bernante P, Rossi GP et al. The role of adrenal venous sampling in the surgical management of primary aldosteronism. World J Surg 2006; 30: 624-627.

54. Tan YY, Ogilvie JB, Triponez F et al. Selective use of adrenal venous sampling in the lateralization of aldosterone-producing adenomas. World J Surg 2006; 30: 879-885.

55. Plouin PF, Rossignol P, Amar L. Selection of patients for surgery for primary aldosteronism. Clin Exp Pharmacol Physiol 2008; 35: 522-525.

56. Zennaro $\mathrm{MC}$, Jeunemaitre $\mathrm{X}$, Boulkroun $\mathrm{S}$. Integrating genetics and genomics in primary aldosteronism. Hypertension 2012; 60: 580-588.

57. Funder JW. The genetic basis of primary aldosteronism. Curr Hypertens Rep 2012; 14: 120-124.

58. Carey RM. Role of $\mathrm{K}^{+}$channels in the pathophysiology of primary aldosteronism. Hypertension 2012; 59: 534-536

59. Choi M, Scholl UI, Yue P et al. K+ channel mutations in adrenal aldosterone-producing adenomas and hereditary hypertension. Science 2011; 331: 768-772.

60. Boulkroun S, Beuschlein F, Rossi GP et al. Prevalence, clinical, and molecular correlates of KCNJ5 mutations in primary aldosteronism. Hypertension 2012; 59: 592-598.

61. Azizan EA, Murthy M, Stowasser M et al. Somatic mutations affecting the selectivity filter of KCNJ5 are frequent in 2 large unselected collections of adrenal aldosteronomas. Hypertension. 2012; 59: 587-591.

62. Funder JW. The genetic of primary aldosteronism Chapter two. Hypertension 2012; 59: 537-538.

63. Gomez-Sanchez CE, Gomez-Sanchez EP. Mutations of the potassium channel KCNJ5 causing aldosterone-producing adenomas: one or two hits? Hypertension 2012; 59: 196-197.

64. Mulatero P, Tauber P, Zennaro MC et al. KCNJ5 mutations in European families with nonglucocorticoid remediable familial hyperaldosteronism. Hypertension 2012; 59: 235-240.

65. Scholl UI, Nelson-Williams C, Yue P et al. Hypertension with or without adrenal hyperplasia due to different inherited mutations in the potassium channel KCNJ5. Proc Natl Acad Sci U S A 2012; 109: 2533-2538.

66. Lin $\mathrm{YH}, \mathrm{Wu} \mathrm{XM}$, Lee HH et al. Adrenalectomy reverses myocardial fibrosis in patients with primary aldosteronism. Hypertens 2012; 30: 1605-1613.

67. Van der Linden P, Steichen O, Zinzindohoue F et al. Blood pressure and medication changes following adrenalectomy for unilateral primary aldosteronism: a follow-up study. Hypertens 2012; 30: 761-769.

68. Reincke M, Fisher E, Gerum S et al. Observational study mortality in treated primary aldosteronism: the German Conn's Registry. Hypertension 2012; 60: 618-624.

69. Karagiannis A, Tziomalos K, Kakafika A et al. Spironolactone versus eplerenone for the treatment of idiopathic hyperaldosteronism. Expert Opin Pharmacother 2008; 9: 509-515.

70. Parthasarathy HK, Menard J, White WB et al. A double-blind randomized study comparing the antihypertensive effect of eplerenone and spironolactone in patients with hypertension and evidence of primary aldosteronism. Hypertens 2011; 29: 980-990.

71. Sechi LA, Novello M, Lapenna R et al. Long-term renal outcomes in patients with primary aldosteronism. JAMA 2006; 295: 2638-2615.

72. Catena C, Colussi G, Nadalini E et al. Relationships of plasma renin levels with renal function in patients with primary aldosteronism. Clin J Am Soc Nephrol 2007; 2: 722-731.

73. Colussi G, Catena C, Sechi L. Spironolactone, eplerenone and the new aldosterone blockers in endocrine and primary hypertension. J Hypertens 2013; 31: 3-15. 